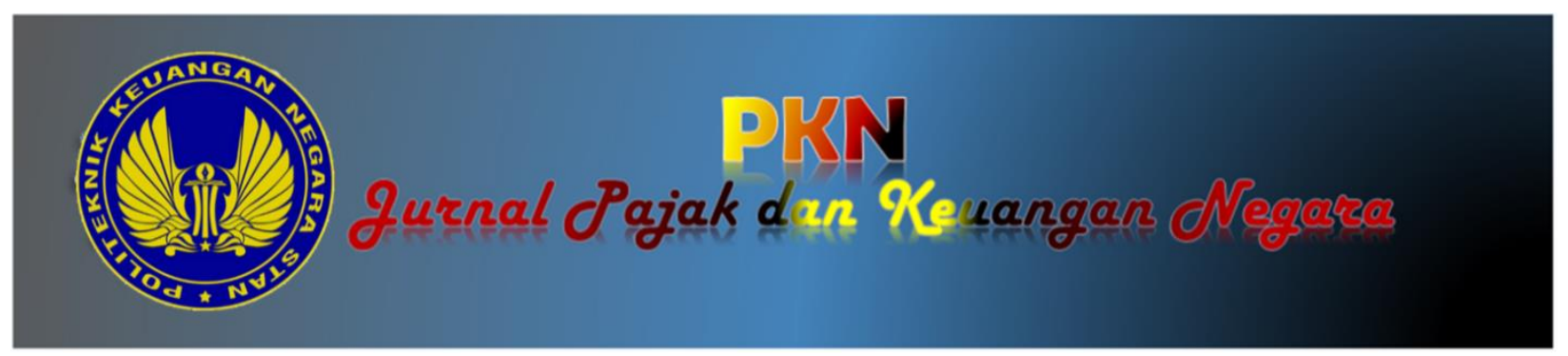

\title{
ANALISIS KEBIJAKAN PENGEMBALIAN PPN (VAT REFUND) DI BANDARA INTERNASIONAL NGURAH RAI UNTUK MENINGKATKAN JUMLAH KUNJUNGAN WISATAWAN ASING DI INDONESIA
}

\author{
Irwan Aribowo \\ PKN STAN-FIA Universitas Brawijaya \\ Gede Angga Ardiana \\ PKN STAN- Direktorat Jenderal Pajak
}

Alamat Korespondensi: irwan_aribowo@pknstan.ac.id

\section{INFORMASI ARTIKEL}

Diterima Pertama

[9 April 2020]

Dinyatakan Diterima

[16 September 2020]

KATA KUNCI:

VAT refund, tax refund, tourism, foreign tourist visits

\section{KLASIFIKASI JEL:}

[Untuk klasifikasi keywords menggunakan standard JEL codes yang dapat diakses pada http://www.aeaweb.org/jel/guide/jel.php]. [Calibri, 9, Regular].

\section{ABSTRACT}

This research was conducted to find out the role of the Tax Return policy in order to increase the number of tourist visits in Indonesia and to study not olny any aspects related to the implementation of the Tax Return policy in Indonesia but also the solutions to overcome it. To achieve tourist visits in Indonesia, additional strategies are needed, one of which is the VAT refund policy for foreign tourists. This money refund is made as an incentive for foreign tourists in order to make them interested on visiting Indonesia. A qualitative approach is used in this study, precisely by using case studies. The results of the study show that VAT refund policy in Indonesia is not effective enough to increase the number of tourist visits to Indonesia. It can be derived by the minimum amount submitted for refunding foreign money. There are several problems in implementing VAT Refund at Ngurah Rai International Airport, including limited money supply, lack of information received by foreign tourists, language disturbances and system problems with the VAT Refund for Tourists Application.

\section{ABSTRAK}

Penelitian ini dilakukan untuk mengetahui bagaimana peran kebijakan VAT Refund di Indonesia terhadap peningkatan jumlah kunjungan wisatawan asing di Indonesia dan untuk lebih mengetahui tentang masalah yang ada dalam pelaksanaan kebijakan pengembalian PPN di Indonesia serta solusi-solusi untuk mengatasinya. Untuk mencapai jumlah kunjungan wisatawan asing dibutuhkan berbagai strategi ekstra diantaranya adalah melalui kebijakan pengembalian PPN atau yang sering dikenal dengan isntilah VAT Refund khususnya bagi wisatawan asing. Pengaturan terkait VAT Refund ini dibuat sebagai insentif bagi wisatawan asing agar tertarik untuk berkunjung ke Indonesia. Dalam penelitian ini digunakan pendekatan kualitatif, lebih tepatnya dengan menggunakan studi kasus. Hasil penelitian berkaitan dengan Pengembalian PPN di Indonesia yang belum cukup efektif untuk meningkatkan jumlah kunjungan wisatawan ke Indonesia.. Hal ini dibuktikan dengan minimnya jumlah wisatawan asing yang mengajukan permohonan pengembalian. Terdapat beberapa masalah dalam pelaksanaan VAT Refund di Bandara Internasional Ngurah Rai, antara lain terbatasnya saldo Uang Persediaan, minimnya informasi yang diterima wisatawan asing, kendala bahasa dan gangguan sistem Aplikasi VAT Refund for Tourists. 
Jurnal Pajak dan Keuangan Negara Vol. II, No.1, (2020), Hal.13-19

P a g e | 14

\section{PENDAHULUAN}

\subsection{Latar Belakang}

Peran sektor pariwisata di negara Indonesia tidak kalah penting dalam perekonomian negara apabila dibandingkan dengan sumber-sumber utama devisa negara lainnya, antara lain ekspor minyak bumi dan gas bumi (migas), batu bara, kelapa sawit, dan industri hasil karet. Sejak tahun 2011, penambahan cadangan devisa Indonesia dari sektor pariwisata terus meningkat dan termasuk empat besar penyumbang devisa terbesar negara.

Devisa yang disumbangkan dari sektor pariwisata selalu meningkat, dari sekitar \$8.5 miliar pada tahun 2011 menjadi \$15.2 miliar pada tahun 2017. Hal ini berbanding terbalik dengan sektor lainnya yang stagnan dan cenderung menurun, terutama dari sektor minyak dan gas bumi. Arief Yahya selaku Menteri Pariwisata memproyeksikan bahwa sektor pariwisata di Indonesia menjadi penyumbang devisa paling besar di tahun 2019 dengan pencapaian nilai sebesar \$24 miliar dolar AS sehingga melampaui devisa yang bersumber dari sektor migas dan minyak kelapa sawit (Republika.co.id, 2017). Besarnya penerimaan devisa dari sektor pariwisata tidak dapat terlepas dari jumlah wisatawan mancanegara yang melakukan kunjungan dan besarnya uang yang digunakan untuk belanja oleh wisatawan selama berada dan tinggal di Indonesia.

Gambar 1.1 Grafik Perkembangan Jumlah Devisa Empat Sektor Utama di Indonesia

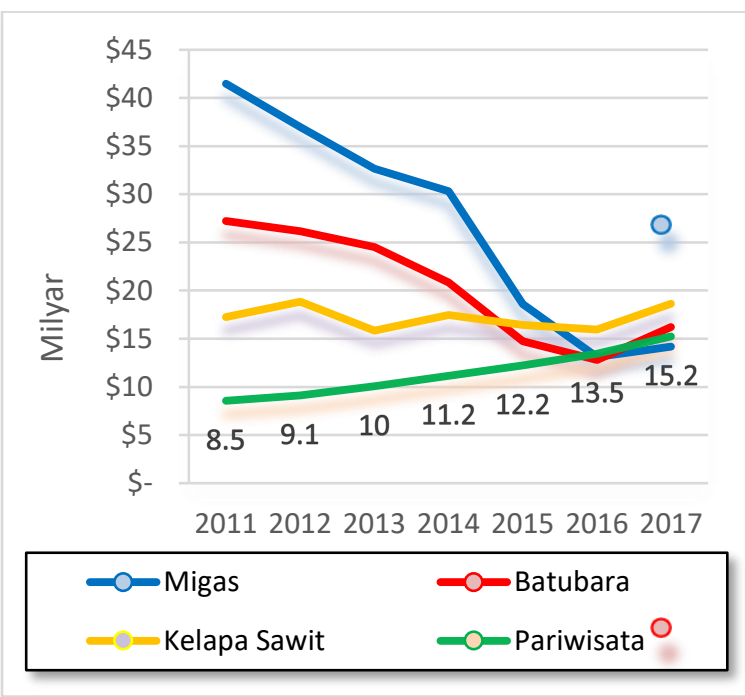

Sumber: diolah dari data BPS dan Kementerian Pariwisata Republik Indonesia

Jumlah kunjungan wisatawan mancanegara ke Indonesia sejak tahun 2011 hingga 2017 selalu meningkat dengan persentase peningkatan dari 5 hingga 16 persen setiap tahunnya. Hal ini tentu sejalan dengan peningkatan jumlah belanja yang dilakukan wisatawan luar negeri yang berkunjung di Indonesia dimana terus mengalami peningkatan sejak tahun 2011 hingga 2017. Pada Tahun 2011, Indonesia dikunjungi 7,65 juta wisatawan mancanegara dengan jumlah pengeluaran sebesar \$8,55 miliar. Sedangkan pada tahun 2016 jumlah kunjungan wisatawan luar negeri ke Indonesia sudah menyentuh angka 11,52 juta kunjungan dengan jumlah pengeluaran sebanyak $\$ 13,27$ miliar. Sedangkan di tahun 2017, jumlah kunjungan wisatawan luar negeri ke Indonesia sudah mencapai angka 14 juta.

Salah satu strategi lain yang dapat dilakukan oleh pemerintah untuk dapat menarik minat wisatawan luar negeri untuk berkunjung di Indonesia yaitu dengan melalui kebijakan fiskal atau perpajakan. Kebijakan fiskal yang dapat distrategikan yaitu dengan memberikan insentif fiskal berupa tax refund atau pengembalian pajak PPN (VAT Refund) bagi wisatawan luar negeri yang berkunjung ke Indonesia.

Kebijakan yang sudah mulai berlaku sejak tanggal 1 April 2010 ini disadari akan menimbulkan potential loss berupa penurunan pendapatan negara dari sisi PPN, tetapi dalam jangka panjang kebijakan ini diharapkan akan meningkatkan penerimaan dari sisi Pajak Penghasilan dan mendorong pertumbuhan ekonomi secara makro. Kebijakan ini diharapkan dapat mendorong jumlah wisatawan mancanegara yang berkunjung dan berbelanja di Indonesia akan semakin meningkat, serta menimbulkan efek berantai pada peningkatan cadangan devisa negara, pertumbuhan ekonomi negara dan penciptaan lapangan pekerjaan baru.

Saat ini dukungan fiskal pemerintah Indonesia terhadap sektor pariwisata melalui VAT Refund ini masih belum cukup efektif. Hal ini terlihat dari minimnya jumlah wisatawan asing yang memanfaatkan fasilitas VAT Refund. Dalam 5 tahun terakhir, hanya 0,027\% wisatawan asing yang datang ke Indonesia yang memanfaatkan fasilitas VAT Refund ini. Hal ini menunjukkan kebijakan ini belum populer di mata wisatawan asing yang datang ke Indonesia.

Penelitian ini dilakukan untuk mengetahui bagaimana pelaksanaan VAT Refund di Indonesia dan menggali lebih dalam mengenai faktor-faktor penyebab minimnya pemanfaatan VAT Refund di Indonesia serta strategi yang dapat dilakukan pemerintah untuk mengatasinya. Penelitian ini dilakukan di salah satu bandara yang melayani pengajuan permohonan VAT Refund di Indonesia yaitu Bandara Internasional Ngurah Rai. Bandara Internasional Ngurah Rai dipilih sebagai objek penelitian dikarenakan bandara ini merupakan bandara yang paling banyak menerima kunjungan wisatawan asing di Indonesia serta menjadi bandara yang paling banyak melayani pengajuan VAT Refund di Indonesia.

\section{LANDASAN TEORI}

\subsection{Fungsi Pajak Secara Umum}

Secara umum, fungsi pajak dibagi menjadi 2 (dua) yaitu sebagai fungsi anggaran (budgeter) dan sebagai fungsi mengatur (regulerend). Mardiasmo (2018) menyebutkan bahwa sebagai fungsi anggaran pajak merupakan salah satu sumber keuangan bagi pemerintah guna membiayai pengeluaran atau belanjanya. Sedangkan pajak sebagai fungsi 
Jurnal Pajak dan Keuangan Negara Vol. II, No.1, (2020), Hal.13-19

Irwan Aribowo, Gede Angga Ardiana

regulerend mempunyai maksud bahwa pajak mempunyai fungsi sebagai alat dalam mengatur kebijakan pemerintah dalam bidang sosial maupun ekonomi.

Resmi (2017) menjelaskan bahwa fungsi budgetair dalam perpajakan adalah bahwa pajak menjadi salah satu sumber bagi penerimaan pemerintah yang digunakan untuk membiayai pengeluaran atau belanja pemerintah baik yang rutin maupun maupun yang bersifat pembangunan. Sedangkan fungsi pajak sebagai pengatur mempunyai maksud bahwa pajak sebagai alat yang dapat digunakan untuk mengatur atau menjalankan kebijakan pemerintah dalam bidang sosial maupun bidang ekonomi. Selain itu, pajak juga dapat digunakan untuk mencapai tujuan tertentu di luar bidang keuangan (Resmi, 2017). Contoh penggunaan pajak sebagai dalam fungsi sebagai pengatur antara lain adalah sebagai berikut:

1. Pengenaan pajak yang tinggi untuk barangbarang kategori mewah. Dalam hal ini, pengenaan Pajak penjualan atas Barang Mewah (PPnBM) dapat dilakukan ketika terjadi transaksi jual beli terhadap barang mewah tersebut. Pengenaan pajak PPnBM ini dimaksudkan agar rakyat dapat mengurangi konsumsi terhadap barang-barang mewah.

2. Pengenaan tarif pajak yang progresif juga dapat dikenakan terhadap penghasilan dengan tujuan agar pihak yang mendapatkan penghasilan tinggi dapat membayar pajak yang lebih tinggi pula sehingga dapat menciptakan pemerataan terhadap pendapatan.

3. Pengenaan tarif pajak ekspor sebesar $0 \%$ (nol persen) digunakan untuk mendorong para pengusaha agar melakukan ekspor hasil produksinya ke luar negeri sehingga dapat mengakibatkan devisa negara yang meningkat.

4. Pengenaan pajak penghasilan atas penyerahan barang-barang hasil industri tertentu seperti misalnya industri rokok, industri semen, industri baja, dan industri lainnya. Hal ini dimaksudkan untuk menekan produksi yang berdampak pada pencemaran lingkungan.

Fungsi pajak dalam perkembangannya mengalami pertambahan 2 (dua) fungsi baru yaitu pajak sebagai fungsi demokrasi dan pajak sebagai fungsi redistribusi. Dengan demikian terdapat 4 (empat) fungsi dari pajak (Susi, 2011). Keempat fungsi pajak tersebut dapat diuraikan sebagai berikut:

1. Pajak sebagai fungsi budgeter adalah fungsi pajak di sektor publik. Dalam hal ini pajak berfungsi untuk menghimpun uang pajak sebesar potensinya berdasarkan peraturan yang berlaku. Selanjutnya uang pajak yang sudah terkumpul digunakan untuk membiayai pengeluaran atau belanja negara.

2. Pajak sebagai fungsi regulerend adalah fungsi pajak yang digunakan sebagai suatu alat untuk mencapai tujuan tertentu, tidak semata-mata hanya untuk kepentingan keuangan negara. Untuk kondisi ini, pajak difungsikan sebagai alat untuk mengatur kondisi sosial dan ekonomi negara.

3. Pajak sebagai fungsi demokrasi adalah fungsi pajak sebagai penjelmaan dari wujud sistem gotong royong dalam sistem pemerintahan dalam proses pembangunan dengan tujuan untuk meningkatkan standar pelayanan dan kehidupan. Fungsi demokrasi dalam hal ini sering dihubungkan dengan hak warga negara untuk memperoleh pelayanan yang baik dari pemerintah. Jika warga negara sudah memenuhi kewajibannya dalam membayar pajak kepada negara, maka warga negara tersebut berhak untuk mendapatkan haknya yaitu mendapatkan pelayanan yang terbaik dari pemerintah.

4. Pajak sebagai fungsi redistribusi adalah fungsi pajak yang lebih memberikan tekanan pada sisi keadilan dan pemerataan bagi lapisan masyarakat. Keadaan ini dapat dilihat dari adanya tarif pajak yang bersifat progresif dimana mengenakan pajak lebih besar kepada lapisan masyarakat yang mempunyai penghasilan lebih besar dan pajak yang relatif lebih kecil kepada lapisan masyarakat yang mempunyai penghasilan relatif sedikit.

Pajak secara umum terdiri atas pajak pusat dan pajak daerah. Contoh pajak pusat adalah seperti PPh, PPN, PPnBM, Bea Meterai, dan PBBP3 (Pertambangan, Perhutanan, dan Perkebunan). Sedangkan pajak daerah contohnya seperti pajak hotel dan restorant.

\subsection{Pajak Pertambajan Nilai (PPN)}

Pajak Pertambahan Nilai (PPN) yaitu pajak yang dikenakan atas konsumsi barang dan jasa di Daerah Pabean. PPN dikenakan secara bertingkat pada jalur produksi maupun distribusi. PPN termasuk dalam jenis pajak yang pengenaannya tidak langsung yang penyetorannya dilakukan oleh pihak lain yang dalam hal ini adalah penjual yang bukan sebagai konsumen akhir.

Rusjdi (2004) dalam bukunya yang berjudul PPN \& PPnBM, menyebutkan bahwa PPN mempunyai beberapa fungsi antara lain:

1) fungsi untuk pendapatan negara

2) fungsi untuk pemerataan beban terhadap pajak

3) fungsi untuk mengatur konsumsi masyarakat

4) fungsi untuk mendorong peningkatan ekspor

5) fungsi untuk meningkatkan investasi

6) fungsi untuk membantu usaha kecil

Menurut Rusjdi (2004), PPN memiliki beberapa karakteristik antara lain:

a. Pajak Tidak Langsung

Dalam kriteria pajak tidak langsung ini, penanggung pajak dan pemikul pajak dilakukan oleh entitas yang berbeda. Penanggung pajak didefinisikan sebagai pihak atau orang yang membayar pajak, sedangkan pemikul pajak adalah pihak atau orang yang secara ketentuan wajib memikul beban pajak. PPN sebagai pajak tidak langsung memenuhi kriteria tersebut, dimana pajak ditanggung oleh konsumen tanpa memandang siapa yang membayarnya dan 
Jurnal Pajak dan Keuangan Negara Vol. II, No.1, (2020), Hal.13-19

$P$ a g e $\mid \mathbf{1 6}$

Irwan Aribowo, Gede Angga Ardiana

pajak dipikul atau dipungut oleh penjual yang secara ketentuan harus membayarkan pajak ke kas negara.

\section{b. Pajak Objektif}

Pajak obektif didefinisikan sebagai pajak pengenaannya didasarkan pada objeknya, seperti barang, jasa, peristiwa atau kejadian dimana dalam Undang-Undang PPN 1984 peristiwa atau keadaan itu disebut penyerahan.

\section{c. Pajak Pusat}

PPN adalah pajak yang diatur berdasarkan undang-undang. PPN termasuk pajak pusat yang pengelolaannya diatur oleh Pemerintah Pusat.

\subsection{Peraturan Terkait VAT Refund di Indonesia}

Mekanisme pendaftaran PKP Toko Retail bagi Wajib Pajak PKP yang ingin bergabung dalam skema VAT Refund diatur dalam Peraturan Direktur Jenderal Pajak Nomor PER-28/PJ/2013. Berdasarkan PER28/PJ/2013, PKP yang ingin ikut dalam skema VAT Refund sebelumnya harus mengajukan permohonan untuk mendapatkan surat keputusan penunjukan PKP Toko Retail dan PIN.

Dengan menggunakan aplikasi VAT Refund for Tourists yaitu aplikasi yang digunakan oleh Direktorat Jenderal Pajak (DJP) untuk mendukung proses pengadministrasian pengembalian Pajak Pertambahan Nilai kepada orang pribadi yang memegang paspor luar negeri.

\subsection{Pengajuan Permohonan VAT Refund oleh Wisatawan Asing (Luar Negeri)}

Pengaturan pengajuan VAT Refund oleh wisatawan asing (Luar Negeri) diatur dalam Peraturan Menteri Keuangan Republik Indonesia Nomor: 76/PMK.03/2010. Berdasarkan Pasal 3 Ayat (1) peraturan ini, pemberian VAT Refund hanya dapat dilakukan atas permintaan wisatawan asing.

\section{METODE PENELITIAN}

Metode yang digunakan dalam penelitian ini adalah metode kualitatif. Dasar pemilihan metode ini karena penulis membutuhkan pemahaman yang lengkap dan rinci tentang masalah yang diteliti. Penulis menggunakan metode deskriptif dan kualitatif dari analisis induktif.

\subsection{Jenis dan Sumber Data}

Penelitian ini menggunakan sumber data berupa data sekunder dan narasumber sebagai informan. Data sekunder yang digunakan dalam penelitian ini adalah data yang bersumber dari buku, artikel, jurnal, focus group discussion dan peraturan.

Teknik yang dilakukan dalam mengumpulkan data antara lain dilakukan dengan:

a. Mengumpulkan dan Meneliti.
Penelitian kepustakaan dengan membaca, memahami berbagai literatur, buku, artikel, dan laporan yang terkait dengan tema penelitian.

b. Wawancara Penelitian lapangan dilakukan dengan wawancara langsung dengan sumber data sehingga didapatkan data yang sesuai demgam objek penelitian (in-depth interview). Wawancara dilakukan dengan informan yang dipilih melalui teknik purposive sampling. Peneliti melakukan wawancara kualitatif dengan mengajukan pertanyaan terbuka yang memungkinkan untuk mode percakapan. Melalui mekanisme ini diharapkan dapat menciptakan hubungan antara peneliti dan informan. Selain itu, penelitian juga dilakukan dengan mengajukan pertanyaan terstruktur dan semi-terstruktur lisan dan tulisan, yang dilakukan melalui tatap muka langsung atau dengan media komunikasi lainnya untuk dijawab oleh informan.

\section{HASIL PENELITIAN}

4.1 Tujuan dan Manfaat Diberlakukannya VAT

\section{Refund di Indonesia}

Berdasarkan pendapat dari informan, secara umum ada tiga tujuan yang ingin dicapai dengan adanya kebijakan VAT Refund di Indonesia, yaitu:

a. menjadi insentif bagi wisatawan asing untuk berkunjung ke Indonesia;

b. menstimulus wisatawan asing untuk melakukan lebih banyak belanja di Indonesia; dan

c. melakukan hal yang sama dengan negaranegara lain dalam memperlakukan wisatawan asing yang berkunjung ke negaranya.

Berdasarkan hasil wawancara yang dilakukan penulis terhadap beberapa Toko Retail yang beroperasi di Bali dan beberapa wisatawan asing, didapatkan data bahwa dengan adanya insentif berupa pengembalian PPN ini, wisatawan asing akan terdorong untuk melakukan belanja atau lebih banyak melakukan belanja.

Penyebab minimnya jumlah pengajuan VAT Refund oleh wisatawan asing disebabkan karena beberapa alasan, antara lain: kurangnya promosi yang dilakukan DJP dan Toko Retail, minimnya Toko Retail yang tergabung dalam skema VAT Refund, tingginya batas minimum belanja yang harus dicapai wisatawan asing untuk mendapatkan fasilitas VAT Refund, jangka waktu pengajuan permohonan yang terlalu singkat dan terbatasnya konter yang melayani pengajuan permohonan VAT Refund.

\subsection{Kontribusi VAT Refund}

Sebagian besar informan berpendapat bahwa VAT Refund kurang berkontribusi terhadap target kunjungan wisatawan luar negeri (mancanegara) pada tahun 2020. Hal ini dikarenakan Indonesia 
bukan merupakan negara destinasi wisata belanja, sedangkan VAT Refund sendiri merupakan fasilitas yang akan didapat turis asing apabila ia melakukan belanja. Apabila Indonesia diarahkan untuk menjadi tujuan wisata belanja, melalui peningkatan kualitas dan kuantitas produk yang ditawarkan serta pembangunan sentra-sentra pusat perbelanjaan, maka pada kondisi tersebut VAT Refund akan dapat lebih berkontribusi terhadap minat wisatawan mancanegara untuk berkunjung ke Indonesia.

\subsection{Rendahnya Tingkat Partisipasi Pengusaha yang} Tergabung Dalam Skema VAT Refund

Berdasarkan hasil wawancara terhadap beberapa informan terkait, diperoleh informasi bahwa penyebab minimnya Toko Retail yang bergabung dalam skema VAT Refund adalah karena alasan-alasan sebagai berikut:

a. tingginya batas minimum belanja yang harus dicapai wisatawan asing untuk mendapatkan fasilitas VAT Refund; dan

b. mekanisme pendaftaran PKP dan Toko Retail yang dianggap menyulitkan bagi Wajib Pajak Pengusaha.

\section{KESIMPULAN DAN SARAN}

\subsection{Kesimpulan}

a. VAT Refund ternyata belum banyak berkontribusi pada peningkatan kunjungan wisatawan asing sehingga belum mendukung pula di sektor pariwisata Indonesia.

b. Terdapat beberapa masalah dalam pelaksanaan VAT Refund di Bandara Internasional Ngurah Rai, antara lain:

- terbatasnya saldo Uang Persediaan;

- minimnya informasi yang diterima wisatawan asing;

- kendala bahasa; dan

- gangguan sistem Aplikasi VAT Refund for Tourists.

c. Terdapat beberapa hal yang menyebabkan minimnya pemanfaatan VAT Refund oleh wisatawan asing dan Toko Retail di Indonesia

d. Terdapat beberapa usulan perbaikan yang diusulkan berbagai pihak untuk memperbaharui kebijakan VAT Refund di Indonesia, antara lain:

- memperbanyak promosi dan penyebaran informasi;

- mengadakan sosialisasi kepada Wajib Pajak Pengusaha yang belum bergabung dalam skema VAT Refund;

- menurunkan batas minimum belanja yang harus dicapai wisatawan asing untuk mendapatkan fasilitas VAT Refund;

- memperpanjang jangka waktu pengajuan permohonan VAT Refund;

- menambah jumlah lokasi pengajuan permohonan VAT Refund; mengubah beberapa mekanisme dan proses bisnis VAT Refund;

PPN atas perolehan barang berupa makanan dan minuman oleh-oleh dapat diminta kembali; dan

- menggunakan jasa pihak ketiga.

\subsection{Rekomendasi}

a. Institusi pajak perlu mempertimbangkan VAT Refund for Tourists menjadi salah satu layanan unggulan mengingat potensi perannya terhadap pengembangan pariwisata di Indonesia.

b. Perlu dilakukan koordinasi antara institusi pajak dengan Kementerian Pariwisata untuk bekerjasama dalam mempromosikan kebijakan VAT Refund agar dapat lebih berperan dalam meningkatkan pengeluaran/belanja dan kunjungan wisatawan asing ke Indonesia.

c. Institusi pajak perlu lebih banyak melibatkan asosiasi Toko Retail, hotel dan pemandu wisata untuk membantu menyebarkan informasi mengenai VAT Refund kepada para wisatawan asing.

d. Institusi pajak perlu mendata masalahmasalah yang sering terjadi dalam proses pengajuan dan penyelesaian permohonan VAT Refund dan membuat aturan atau solusi untuk mengatasi permasalahanpermasalahan tersebut.

e. Institusi pajak perlu mengkaji dan menerapkan beberapa usulan pembaharuan kebijakan yang diajukan oleh pihak-pihak terkait dalam rangka membuat fasilitas VAT Refund lebih banyak dimanfaatkan oleh wisatawan asing.

f. Untuk penelitian selanjutnya perlu dilakukan wawancara secara mendalam kepada wisatawan asing selaku pihak yang memanfaatkan kebijakan VAT Refund termasuk di beberapa bandara lainnya.

\subsection{Ketebatasan}

a. Penelitian ini dilakukan dengan mengamati pelaksanaan VAT Refund bagi wisatawan asing di UPR PPN Bandara Internasional Ngurah Rai yang mungkin memiliki kondisi berbeda dengan bandara lainnya di Indonesia.

b. Penelitian ini kurang melibatkan secara mendalam wisatawan asing selaku pihak yang memanfaatkan adanya kebijakan VAT Refund.

c. Penelitian ini dilakukan pada pertengahan tahun 2011 dimana pada tahun itu pelaksanaan VAT Refund baru berlangsung selama 1 tahun terakhir dan beberapa bandara baru ditunjuk melayani VAT Refund 
pada tahun tersebut, sehingga data yang ditampilkan pada penelitian ini masih sedikit dan belum dapat digunakan untuk menilai dan menganalisis penerapan kebijakan ini secara keseluruhan.

\section{DAFTAR PUSTAKA}

Budiarto, Muhammad Taufiq. 2015. Menelisik Threshold Restitusi PPN Bagi Turis Asing. Diakses 30 September 2018 dari http://www.bppk.kemenkeu.go.id/pu blikasi/artikel/167-artikel-

pajak/21108-menelisik-

thresholdrestitusi-ppn-bagi-turisasing.

Kodyat, H.. 1996. Sejarah Pariwisata dan Perkembangannya di Indonesia. Jakarta: Liberty.

Hadinoto, Kusudianto. 1996. Perencanaan dan Pengembangan Destinasi Pariwisata. Jakarta: UI Press.

Huberman, Michael A \& Miles, Mathew B. Penerjemah Tjetjep Rohendi. 2009. Analisis Data Kualitatif Buku Sumber Tentang Metode-Metode Baru. Jakarta: UI Press.

Rusjdi, Muhammad. 2004. PPN \& PnBM. Jakarta: PT. Indeks.

Sugiyono. 2016. Metode Penelitian Kuantitatif, kualitatif dan $R$ \& $D$. Bandung: Alfabeta.

Siti Resmi. 2017. Perpajakan: Teori dan Kasus. Jakarta: Salemba Empat.

Mardiasmo. 2018. Perpajakan. Yogyakarta: Andi. Jurnal dan Sumber Lainnya

Yamashita, S. 2015. Tourism. International Encyclopedia of the Social \& Behavioral Sciences, 24(1996), 465468. https://doi.org/10.1016/B978-008-097086-8.12157-9.

Ragimun. 2011. Analisis Kebijakan Tax Refund Wisatawan Asing Di Indonesia. Diakses 30 September 2018 dari https://www.kemenkeu.go.id/sites/de fault/files/Analisis\%20Kebijakan\%20Ta $\mathrm{x} \% 20$ Refund\%20Wisatawan\%20Asing \%20di\%20Indonesia.pdf.

Aida, Ade Nurul. 2018. A Menimbang Kembali Kebijakan Tax Refund Wisatawan Mancanegara (Wisman). Diakses 30 September 2018 dari http://berkas.dpr.go.id/puskajianggar an/buletin-apbn/public-file/buletinapbn-public-66.pdf.

Pramana, Aditya Putra, Mochammad AL Musadieq \& Rosalita Rachma Agusti. 2013. Analisis Pelaksanaan Pengembalian PPN untuk Turis Asing (VAT Refund). Diakses 30 September 2018 dari http://perpajakan.studentjournal.ub.a c.id/index.php/perpajakan/article/vie $w / 251$.

Hessy Erlisa Frasti. 2018. Prinsip Pengenaan PPN: Mengapa Harus Destination Principle? Diakses 15 Desember 2018 dari https://news.ddtc.co.id/mengapaharus-destination-principle-12220.

Yamashita, S. 2015. Tourism. International Encyclopedia of the Social \& Behavioral Sciences, 24(1996), 465468. https://doi.org/10.1016/B978-008-097086-8.12157-9.

Budiarto, Muhammad Taufiq. 2015. Menelisik Threshold Restitusi PPN Bagi Turis Asing. Diakses 30 September 2018 dari http://www.bppk.kemenkeu.go.id/pu blikasi/artikel/167-artikelpajak/21108-menelisikthresholdrestitusi-ppn-bagi-turisasing.

Ragimun. 2011. Analisis Kebijakan Tax Refund Wisatawan Asing Di Indonesia. Diakses 30 September 2018 dari https://www.kemenkeu.go.id/sites/de fault/files/Analisis\%20Kebijakan\%20Ta x\%20Refund\%20Wisatawan\%20Asing \%20di\%20Indonesia.pdf.

Aida, Ade Nurul. 2018. A Menimbang Kembali Kebijakan Tax Refund Wisatawan Mancanegara (Wisman). Diakses 30 September 2018 dari http://berkas.dpr.go.id/puskajianggar an/buletin-apbn/public-file/buletinapbn-public-66.pdf.

Pramana, Aditya Putra, Mochammad AL Musadieq \& Rosalita Rachma Agusti. 2013. Analisis Pelaksanaan Pengembalian PPN untuk Turis Asing (VAT Refund). Diakses 30 September 2018 dari http://perpajakan.studentjournal.ub.a c.id/index.php/perpajakan/article/vie $\mathrm{w} / 251$.

Undang-Undang Nomor 28 Tahun 2007 tentang Perubahan Ketiga Atas UndangUndang Nomor 6 Tahun 1983 Tentang Ketentuan Umum Dan Tata Cara Perpajakan.

Undang-Undang Nomor 36 Tahun 2008 tentang Perubahan Keempat atas UndangUndang Nomor 7 Tahun 1983 Tentang Pajak Penghasilan.

Undang-Undang Nomor 10 Tahun 2009 tentang Kepariwisataan.

Undang-Undang Nomor 42 Tahun 2009 tentang Perubahan Ketiga atas UndangUndang Nomor 8 Tahun 1983 tentang Pajak Pertambahan Nilai Barang dan 
Jasa dan Pajak Penjualan Atas Barang Mewah.

Undang-Undang Nomor 6 Tahun 2011 tentang Keimigrasian.

Peraturan Menteri Keuangan Nomor 76/PMK.03/2010 tentang Tata Cara Pengajuan Dan Penyelesaian Permintaan Kembali Pajak Pertambahan Nilai Barang Bawaan Orang Pribadi Pemegang Paspor Luar Negeri.

Peraturan Direktur Jenderal Pajak Nomor PER28/PJ/2013 tentang Tata Cara Pendaftaran dan Kewajiban Pengusaha Kena Pajak Toko Retail serta Pengelolaan Administrasi Pengembalian Pajak Pertambahan Nilai Kepada Orang Pribadi Pemegang Paspor Luar Negeri.

Negeri dan Peraturan Direktur Jenderal Pajak Nomor PER-20/PJ/2010 tentang Tata Cara Pendaftaran dan Kewajiban Toko Retail serta Kantor Pelayanan Pajak yang Mengelola Administrasi Pengembalian Pajak Pertambahan Nilai Kepada Orang Pribadi Pemegang Paspor Luar Negeri.

Surat Edaran Direktur Jenderal Pajak Nomor SE57/PJ/2010 tentang Tata Cara Pengajuan Uang Persediaan, Penggantian Uang Persediaan, dan Pembayaran Pengembalian Pajak Pertambahan Nilai Barang Bawaan Orang Pribadi Pemegang Paspor Luar Negeri.

Surat Edaran Direktur Jenderal Pajak Nomor SE39/PJ/2013 tentang Tata Cara Pengembalian dan Pengelolaan Administrasi Pajak Pertambahan Nilai Kepada Orang Pribadi Pemegang Paspor Luar Negeri.

Republika.co.id. (2017). Pariwisata Diproyeksi Hasilkan Devisa Terbesar Nasional. Diakses 30 September 2018 dari http://www.republika.co.id/berita/ek onomi/makro/17/10/16/ekonomi/ma kro/17/10/17/oxymd5382-pariwisatadiproyeksi-hasilkan-devisa-terbesarnasional.

Zulvina, Susi. 2011. Bahan Ajar Pengantar Hukum Pajak. 